\title{
Generation of nitryl chloride from chlorotrimethylsilane-acetyl nitrate reaction: A one-pot preparation of gem-chloronitro compounds from oximes
}

\author{
ABDULKARIM H A MOHAMMED and GOPALPUR NAGENDRAPPA* \\ Department of Chemistry, Bangalore University, (Central College Campus), Bangalore 560001 \\ e-mail: gnagendrappa@gmail.com
}

MS received 23 September 2009; revised 31 March 2010; accepted 6 April 2010

\begin{abstract}
While iso-amyl nitrite reacts with chlorotrimethylsilane to give NOCl, iso-amyl nitrate does not yield $\mathrm{NO}_{2} \mathrm{Cl}$ with silicon reagent. However, acetyl nitrate reacts successfully with chlorotrimethylsilane to give nitryl chloride, which is characterized by its UV spectrum. If it is generated in presence of ketoximes, gem-chloronitro as well as gem-chloronitroso compounds are formed in almost equal amounts, which together account for up to $80 \%$ yield. This is possibly the simplest one-pot reaction for the preparation of gem-chloronitro compounds which find several synthetic applications. If $\mathrm{NO}_{2} \mathrm{Cl}$ is generated in presence of cycloalkenes, the corresponding 1,2-dichlorocycloalkanes are obtained. Considering the evidence in hand, it is proposed that $\mathrm{NO}_{2} \mathrm{Cl}$, initially formed by chlorotrimethylsilane-acetyl nitrate reaction, decomposes to $\mathrm{Cl}_{2}$, and $\mathrm{N}_{2} \mathrm{O}_{4}$. Then chlorine reacts with oximes to produce first gemchloronitroso compounds, which are oxidized by $\mathrm{NO}_{2} \mathrm{Cl}$ or $\mathrm{N}_{2} \mathrm{O}_{4}$ to gem-chloronitro compounds, and with cycloalkenes it gives dichlorocycloalkanes.
\end{abstract}

Keywords. Nitryl chloride; acetyl nitrate; chlorotrimethylsilane; gem-chloronitro compounds; gemchloronitroso compounds; oximes; chlorination; cycloalkenes.

\section{Introduction}

The smooth and successful reaction of chlorotrimethylsilane (TMSCl) with amyl or iso-amyl nitrite to generate nitrosyl chloride in situ under anhydrous conditions either in the presence or in the absence of a solvent (1) ${ }^{1}$ prompted us to attempt a similar reaction of TMSCl with amyl nitrate for the preparation of nitryl chloride. We found that this simple logic did not work the way it was expected to, as the starting compounds remained totally intact even after stirring for a long time at room temperature (2). However, we discovered that acetyl nitrate reacted efficiently with TMSCl to produce $\mathrm{NO}_{2} \mathrm{Cl}$, (3).

$$
\begin{aligned}
& \left(\mathrm{CH}_{3}\right)_{3} \mathrm{SiCl}+\mathrm{RONO} \stackrel{<0^{\circ} \mathrm{C}}{\longrightarrow} \\
& \mathrm{NOCl}+\left(\mathrm{CH}_{3}\right)_{3} \mathrm{SiOR} \\
& \left(\mathrm{CH}_{3}\right)_{3} \mathrm{SiCl}+\mathrm{RONO}_{2} \stackrel{\mathrm{RT}}{\longrightarrow} \text { No reaction } \\
& \left(\mathrm{CH}_{3}\right)_{3} \mathrm{SiCl}+\mathrm{RCO}_{2} \mathrm{NO}_{2} \stackrel{-10^{\circ} \mathrm{C}}{\longrightarrow} \\
& \mathrm{NO}_{2} \mathrm{Cl}+\mathrm{RCO}_{2} \mathrm{Si}\left(\mathrm{CH}_{3}\right)_{3} .
\end{aligned}
$$

\footnotetext{
*For correspondence
}

The only practical method of preparing nitryl chloride in the laboratory is by the reaction of chlorosulphonic acid with nitric $\operatorname{acid}^{2}$ (4). An old method of its preparation consisted of passing chlorine gas on hot silver nitrate (5). It can be prepared by the oxidation of $\mathrm{NOCl}$ with ozone $\mathrm{e}^{3}(6)$.

$$
\begin{aligned}
& \mathrm{ClSO}_{3} \mathrm{H}+\mathrm{HNO}_{3} \rightarrow \mathrm{NO}_{2} \mathrm{Cl}+\mathrm{H}_{2} \mathrm{SO}_{4} \\
& 2 \mathrm{AgNO}_{3}+2 \mathrm{Cl}_{2} \rightarrow 2 \mathrm{NO}_{2} \mathrm{Cl}+2 \mathrm{AgCl}+\mathrm{O}_{2} \\
& \mathrm{NOCl}+\mathrm{O}_{3} \rightarrow \mathrm{NO}_{2} \mathrm{Cl}+\mathrm{O}_{2}
\end{aligned}
$$

Nitryl chloride is widely recognised as an important product of interaction between chloride ions in sea salt aerosol and $\mathrm{N}_{2} \mathrm{O}_{5}$ present in marine atmosphere, particularly near urban centres that generate huge amounts of nitrogen oxides through fossil fuel burning. The nitryl chloride then dissociates into nitric oxide and chlorine, (7), the latter being responsible for the increased production of ozone in such marine environment. ${ }^{4}$

Nitryl chloride is known to react with unsaturated compounds ${ }^{5 \mathrm{c}, \mathrm{j}, 6}$ to give vic-chloronitro compounds and/or vic-dichloro compounds, ${ }^{2 a, 5}$ and to nitrate ${ }^{6 e, 7}$ 
as well as chlorinate ${ }^{7}$ aromatic compounds. It has been found to chlorinate carbonyl compounds ${ }^{8}$ and strained hydrocarbons. ${ }^{9}$ It is proposed that nitryl chloride formed in vivo may be involved in tyrosine nitration as well as protein modification and tissue injuries. ${ }^{2 c, 10}$

We found that nitryl chloride can be conveniently generated under anhydrous conditions by the reaction of acetyl nitrate with chlorotrimethylsilane and present here the results of its reactions in situ with oximes and olefins.

\section{Experimental}

\subsection{General}

The NMR spectra were recorded on JEOL FX90Q or Bruker AC-250 instrument using $\mathrm{CDCl}_{3}$ as solvent and tetramethylsilane (TMS) as internal standard. The IR spectra were taken on Nicolet Impact 400D single beam instrument using $\mathrm{KBr}$ pellets for solids and as thin film between $\mathrm{NaCl}$ plates in case of liquids. Gas chromatographic (GC) analyses were carried out on a Varian Vista 6000 instrument using $15 \%$ of FFAP on Chromosorb-W column $(2 \times 2 \mathrm{~mm}$ i.d.).

Acetic anhydride and dichloromethane were distilled over $\mathrm{P}_{2} \mathrm{O}_{5}$ before use. Silica gel (Qualigens) used for column chromatography (60-120 mesh size) was activated by heating to $110^{\circ} \mathrm{C}$ before use.

Cyclopentanone, cyclohexanone, cycloheptanone, cyclooctanone, cyclododecanone, norcamphor, camphor, 4-heptanone and propiophenone were obtained from Aldrich chemical company. Acetophenone was obtained from SD Fine Chemicals. Dibenzyl ketone was prepared by the literature procedure. ${ }^{11}$ Hydroxylamine hydrochloride was of A.R. grade.

Cyclopentene, cyclohexene, and cycloheptene were prepared by dehydration of the corresponding alcohols. (Cyclopentanol and cycloheptanol were prepared by reducing cyclopentanone and cycloheptanone using sodium-wet ether.) Cyclooctene, cyclododecene (cis-trans mixture) and norbornene were purchased from Aldrich. Chlorotrimethylsilane, purchased from Spectrochem, was distilled over quinoline (1-2\%).

Acetyl nitrate was prepared according to literature procedure ${ }^{12}$ by adding conc $\mathrm{HNO}_{3}$ (density 1.40 ) to acetic anhydride, freshly distilled over $\mathrm{P}_{2} \mathrm{O}_{5}$. The ketoximes 1-11 were prepared by known method. ${ }^{13}$

All the liquid starting compounds obtained from commercial sources were distilled and their purity was checked by GC before use.

\subsection{General procedure for the reaction of oximes} with $\mathrm{TMSCl}-\mathrm{AcONO}{ }_{2}$

A solution of $10 \mathrm{mmol}$ of oxime in $15 \mathrm{~mL}$ of $\mathrm{CH}_{2} \mathrm{Cl}_{2}$, distilled over $\mathrm{P}_{2} \mathrm{O}_{5}$, was placed in a $100 \mathrm{~mL}$ two-necked flask fitted with a $\mathrm{CaCl}_{2}$ guard tube and a dropping funnel, and cooled to $-10^{\circ} \mathrm{C}$. Chlorotrimethylsilane $(12-13 \mathrm{mmol})$ in $2 \mathrm{~mL}$ of $\mathrm{CH}_{2} \mathrm{Cl}_{2}$ was added drop-wise with stirring. Acetyl nitrate (12-13 mmol, prepared by mixing $12 \mathrm{~mL}$ of $\mathrm{Ac}_{2} \mathrm{O}$ with $2 \mathrm{~mL}$ of conc. $\mathrm{HNO}_{3}$ of density 1.40) was added cautiously over a period of $1-1.5 \mathrm{~h}$. The solution turned blue indicating the formation of chloronitroso derivative. The blue colour persisted even after stirring the reaction mixture for an additional period of $1 \mathrm{~h}$. The reaction mixture was then treated carefully with $20 \mathrm{~mL}$ of ice-cold water. After separating the organic layer, the aqueous layer was extracted with $\mathrm{CH}_{2} \mathrm{Cl}_{2}(2 \times 15 \mathrm{~mL})$. The $\mathrm{CH}_{2} \mathrm{Cl}_{2}$ layers were combined and washed with water $(2 \times 20 \mathrm{~mL}), \quad 5 \% \mathrm{NaHCO}_{3}$ solution $(2 \times 20 \mathrm{~mL})$, again water $(20 \mathrm{~mL})$, and finally with saturated $\mathrm{NaCl}$ solution $(20 \mathrm{~mL})$. After drying over $\mathrm{Na}_{2} \mathrm{SO}_{4}$, the solvent was removed and the residue was chromatographed on silica gel column using petroleum ether (b.p. $50-55^{\circ} \mathrm{C}$ ) as eluant. The regenerated ketone $(8-10 \%)$ passed through first, followed by gem-chloronitroso compound, and finally gemchloronitro compound. The conversion is quantitative (table 1). The products were identified by their spectral data (see tables S1 and S2) (see supporting information). The spectral data of only $9 \mathbf{a}, \mathbf{3 b}$ and $9 \mathbf{b}$, which are not reported in the literature, are tabulated in table 2 in the main text. gem-Chloronitroso compounds were found to be much less stable than the gem-chloronitro compounds.

\subsection{Reaction of cycloalkenes with TMSCl- $\mathrm{AcONO}_{2}$ : Preparation of 1,2-dichlorocycloalkanes}

2.3a General procedure: A solution of $10 \mathrm{mmol}$ of cycloalkene in $5 \mathrm{~mL}$ of $\mathrm{CH}_{2} \mathrm{Cl}_{2}$, distilled over $\mathrm{P}_{2} \mathrm{O}_{5}$, was placed in a $100 \mathrm{~mL}$ round bottomed flask, and cooled to $-10^{\circ} \mathrm{C}$. Chlorotrimethylsilane $(1.40 \mathrm{~g}$, $10.94 \mathrm{mmol}$ ) was added drop-wise from a pressure equalizing dropping funnel fitted with a $\mathrm{CaCl}_{2}$ guard tube. Acetyl nitrate (prepared freshly from $15 \mathrm{~mL}$ of acetic anhydride, distilled over $\mathrm{P}_{2} \mathrm{O}_{5}$ and $1.12 \mathrm{~g}$ of conc. $\mathrm{HNO}_{3}, d, 1.40$ ), in $5 \mathrm{~mL}$ of $\mathrm{CH}_{2} \mathrm{Cl}_{2}$ was added slowly. The reaction mixture was allowed to stir for $2-3 \mathrm{~h}$, and treated with $10 \mathrm{~mL}$ of cold water. The 
Table 1. Reaction of ketoximes with $\mathrm{ClSiMe}_{3}-\mathrm{AcONO}_{2}$

\begin{tabular}{clll}
\hline & & \multicolumn{2}{c}{ Yield $(\mathbf{\%})^{\mathrm{a}}$} \\
\cline { 3 - 4 } Entry & Oxime of & $\begin{array}{c}\text { gem-chloronitroso } \\
\text { Compound }\end{array}$ & $\begin{array}{c}\text { gem-chloronitro } \\
\text { compound }\end{array}$ \\
\hline 1 & Cyclopentanone & $\mathbf{1 a}^{14,15,29 c, 32}(45)$ & $\mathbf{1 b}^{14,22}(32)$ \\
2 & Cyclohexanone & $\mathbf{2 a}^{14-16,29 \mathrm{~d}}(40)$ & $\mathbf{2 b}^{14,22,28,29 \mathrm{~d}}(30)$ \\
3 & Cycloheptanone & $\mathbf{3 a}^{14,32 \mathrm{~d}}(40)$ & $\mathbf{3 b}^{\mathrm{b}}(32)$ \\
4 & Cyclooctanone & $\mathbf{4 a}^{14,32 \mathrm{~d}}(35)$ & $\mathbf{4 b}^{14}(42)$ \\
5 & Cyclododecanone & $\mathbf{5 a}^{14,29 \mathrm{c}}(30)$ & $\mathbf{5 b}^{14,27}(33)$ \\
6 & Norcamphor & $\mathbf{6 a}^{25}(32)$ & $\mathbf{6 b}^{20,21}(35)$ \\
7 & Camphor & $\mathbf{7 a}^{17,26}(30)$ & $\mathbf{7 b}^{18,21,26,29 \mathrm{~d}}(37)$ \\
8 & Acetophenone & $\mathbf{8 a}^{16}(34)$ & $\mathbf{8 b}^{19,20}(30)$ \\
9 & Propiophenone & $\mathbf{9 a}^{\mathrm{b}}(32)$ & $\mathbf{9 b}^{\mathrm{b}}(35)$ \\
10 & 4-Heptanone & $\mathbf{1 0 a}^{24}(45)$ & $\mathbf{1 0 b}^{24}(33)$ \\
11 & Dibenzylketone & $\mathbf{1 1 a}^{23,24}(40)$ & $\mathbf{1 1 b}^{24}(43)$ \\
\hline
\end{tabular}

${ }^{\text {a }}$ Some amount $(8-10 \%)$ of regenerated parent ketone was also isolated.

${ }^{\mathrm{b}} 3 \mathbf{b}, 9 \mathrm{a}$ and $\mathbf{9 b}$ are not known in the literature.

Table 2. Spectral data for $9 a, 3 b$ and $9 b$.

\begin{tabular}{lccc}
\hline Compd. & $\mathrm{IR}, v\left(\mathrm{~cm}^{-1}\right)$ (selected) & ${ }^{1} \mathrm{H} \mathrm{NMR}\left(\mathrm{CDCl}_{3}\right), \delta(\mathrm{ppm})$ & ${ }^{13} \mathrm{C} \mathrm{NMR}\left(\mathrm{CDCl}_{3}\right), \delta(\mathrm{ppm})$ \\
\hline 9a & $2974,2937,2886,1624$ & $($ NMR was not done; & \\
& $1559,1462,1392,1295$, & oxidized to 9b) & \\
& $1086,891,766,678$ & & \\
3b & $2940,2862,1569,1460$, & $2 \cdot 65(m, 2 \mathrm{H}), 2 \cdot 36(\mathrm{~m}, 2 \mathrm{H})$, & $22 \cdot 76,28 \cdot 20,42 \cdot 39$, \\
& $1341,1176,1021,969$ & $1 \cdot 58-1 \cdot 65(m, 8 \mathrm{H})$. & $108 \cdot 59$ \\
9b & $3074,2991,2950,2893$, & $1 \cdot 09(t, 3 \mathrm{H}, J=7 \cdot 5 \mathrm{~Hz})$, & $8 \cdot 75,29 \cdot 11,123 \cdot 51$, \\
& $1559,1455,1352,1326$, & $3 \cdot 02(q, 2 \mathrm{H}, J=7 \cdot 5 \mathrm{~Hz})$, & $128 \cdot 16,128 \cdot 85,129 \cdot 17$, \\
& $1222,912,819,721,700$ & $7 \cdot 43-7.53(m, 5 \mathrm{H})$ & $131 \cdot 69$ \\
\hline
\end{tabular}

Table 3. Reaction of $\mathrm{ClSiMe}_{3}-\mathrm{AcONO}_{2}$ with olefins.

\begin{tabular}{llcc}
\hline Entry & \multicolumn{1}{c}{ 1,2-Dichloro- } & $\begin{array}{c}\text { Reaction } \\
\text { time }(\mathrm{h})\end{array}$ & $\begin{array}{c}\text { Yield } \\
\text { (\%) }\end{array}$ \\
\hline 1 & -cyclopentane & $2 \cdot 0$ & 60 \\
2 & -cyclohexane & $2 \cdot 5$ & 76 \\
3 & -cycloheptane & $2 \cdot 5$ & 70 \\
4 & -cyclooctane & $3 \cdot 0$ & 73 \\
5 & -cyclododecane & $3 \cdot 0$ & 83 \\
6 & 2,3-dichloro-norbornane & $2 \cdot 5$ & 75 \\
\hline
\end{tabular}

layers were separated and the aqueous layer was extracted with $\mathrm{CH}_{2} \mathrm{Cl}_{2}(2 \times 15 \mathrm{~mL})$. The combined $\mathrm{CH}_{2} \mathrm{Cl}_{2}$ extracts were washed with water $(2 \times 15 \mathrm{~mL})$, $5 \% \mathrm{NaHCO}_{3}$ solution $(2 \times 15 \mathrm{~mL})$ and saturated $\mathrm{NaCl}$ solution $(2 \times 15 \mathrm{~mL})$. After drying over $\mathrm{Na}_{2} \mathrm{SO}_{4}$, the solvent was removed and the residue was chromatographed on a silica gel column using petroleum ether $\left(50-55^{\circ} \mathrm{C}\right)$ as eluant to obtain pure 1,2-dichlorocycloalkanes, (table 3). The spectral data are given in table 4. (Authentic samples of 1,2-dichlorocycloalkanes 12a-17a were prepared by passing chlorine to solutions of 1-6 in $\mathrm{CH}_{2} \mathrm{Cl}_{2}$ at $\left.-10^{\circ} \mathrm{C}\right)$.

\section{Results and discussion}

The principal aim of the present study was to know whether TMSCl would react with an organic nitrate to produce nitryl chloride which could be allowed to react in situ with oximes to obtain directly gemchloronitro compounds which have many useful synthetic applications. ${ }^{29}$ Based on the known fact that $\mathrm{NOCl}$ reacts with oximes to produce gemchloronitroso compounds in almost quantitative yield, ${ }^{1 \mathrm{a}, \mathrm{c}, 30}$ we surmised that oximes when reacted with $\mathrm{NO}_{2} \mathrm{Cl}$ might deliver gem-chloronitro compounds. If successful, this would be the simplest 
Table 4. Spectral data of 1,2-dichloro compounds.

\begin{tabular}{lccc}
\hline Entry & Compd. & IR & ${ }^{1} \mathrm{H} \mathrm{NMR}\left(\mathrm{CDCl}_{3}\right)(\delta)$ \\
\hline 1 & $\mathbf{1 c}$ & $2955,2859,1457,1448,1322$, & $3 \cdot 97-4 \cdot 04(\mathrm{~m}, 2 \mathrm{H})$, \\
& & $823,743,721,695$ & $1 \cdot 42-2 \cdot 15(\mathrm{~m}, 6 \mathrm{H})$ \\
2 & $\mathbf{2 c}$ & $2950,2862,1455,1445,1347,1212,990$, & $3 \cdot 9-4 \cdot 2(\mathrm{~m}, 2 \mathrm{H})$, \\
& & $845,745,738,692$ & $1 \cdot 26-2 \cdot 27(\mathrm{~m}, 8 \mathrm{H})$ \\
3 & $\mathbf{3 c}$ & $2943,2867,1446,1455,1259$, & $4 \cdot 15-4 \cdot 44(\mathrm{~m}, 2 \mathrm{H})$, \\
& & $1222,778,757,695,633$ & $1 \cdot 42-3 \cdot 92(\mathrm{~m}, 10 \mathrm{H})$ \\
4 & $\mathbf{4 c}$ & $2934,2862,1475,1449,1244$, & $4 \cdot 21-4 \cdot 29(\mathrm{~m}, 2 \mathrm{H})$, \\
& & $1223,869,833,776,730,678$ & $1 \cdot 35-2 \cdot 30(\mathrm{~m}, 12 \mathrm{H})$ \\
5 & $\mathbf{5 c}$ & $2934,2872,1471,1445,1284$, & $4 \cdot 20-4 \cdot 26(\mathrm{~m}, 2 \mathrm{H})$, \\
& & $1248,891,767,726,736,664$ & $1 \cdot 10-2 \cdot 15(\mathrm{~m}, 20 \mathrm{H})$ \\
6 & $\mathbf{6 c}$ & $2924,2851,1480,1449,1346$, & $3 \cdot 87-3 \cdot 91(\mathrm{~m}, 2 \mathrm{H})$, \\
& & $1253,865,846,782,730,668$ & $1 \cdot 11-2 \cdot 51(\mathrm{~m}, 8 \mathrm{H})$ \\
\hline
\end{tabular}
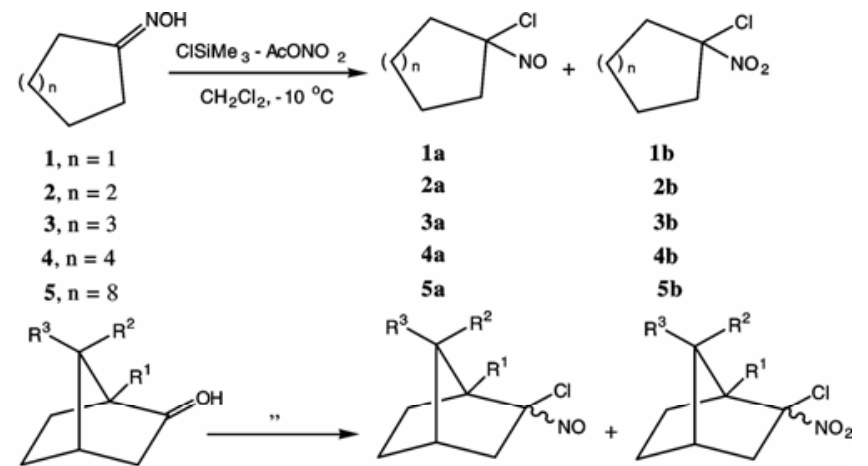

6, $\mathrm{R}^{1}=\mathrm{R}^{2}=\mathrm{R}^{3}=\mathrm{H}$

$7, \mathrm{R}^{1}=\mathrm{R}^{2}=\mathrm{R}^{3}=\mathrm{CH}_{3}$

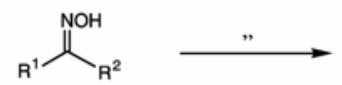

$8, \mathrm{R}^{1}=\mathrm{Ph}, \mathrm{R}^{2}=\mathrm{CH}_{3}$

9, $\mathrm{R}^{1}=\mathrm{Ph}, \mathrm{R}^{2}=\mathrm{C}_{2} \mathrm{H}_{5}$

$10, \mathrm{R}^{1}=\mathrm{R}^{2}=n-\mathrm{C}_{3} \mathrm{H}_{7}$

$11, \mathrm{R}^{1}=\mathrm{R}^{2}=\mathrm{Ph}-\mathrm{CH}_{2}$

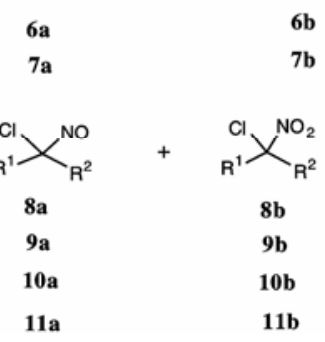

Scheme 1.

one-pot method to prepare gem-chloronitro compounds, as the other known methods involve more complicated two-step reactions. ${ }^{14}$

When the oximes 1-11 in $\mathrm{CH}_{2} \mathrm{Cl}_{2}$ were treated with $\mathrm{TMSCl}$ and $\mathrm{AcONO}_{2}$, gem-chloronitro compounds $\mathbf{1 b}-\mathbf{1 1 b}$ were obtained. However, they were accompanied by almost equal amounts of the corresponding chloronitroso derivatives 1a-11a and small amounts of parent ketones (scheme 1, table 1). The products could be easily separated by chromatography on silica gel column using petroleum ether (b.p. $50-55^{\circ} \mathrm{C}$ ) as eluant. They were identified by their spectral data (see tables S1 and S2, supporting information). All the gem-chloronitroso and gemchloronitro compounds, except $3 \mathbf{b}, 9 \mathbf{a}$ and $9 \mathbf{b}$, are known in the literature (see table 1 for references). The structural assignment of $\mathbf{3 b}, \mathbf{9} \mathbf{a}$ and $\mathbf{9 b}$ is tentative and is based on their spectral data (table 2), and similarity of their characteristics with those of other compounds in their respective group.

The chloronitroso compounds, except solids, decompose gradually even at room temperature. They can be oxidized to chloronitro compounds by treating them again with $\mathrm{TMSCl}$ and $\mathrm{AcONO}_{2}$ or with cetyltrimethylammonium hypochlorite, ${ }^{31}$ thus increasing the total yield of the chloronitro compounds. The chloronitro compounds are far more stable than the chloronitroso compounds

The formation of $\mathrm{NO}_{2} \mathrm{Cl}$ in the mixture of TMSCl and $\mathrm{AcONO}_{2}$ was indicated by the UV spectrum of the mixture. Literature reports describe two absorption peaks for $\mathrm{NO}_{2} \mathrm{Cl}$ in various solvents. One of them is a weak band of fixed $\lambda_{\max }$ at $460 \mathrm{~nm}$ and the other one a strong absorption of variable $\lambda_{\max }$, which depends on the solvent, ranges from $222 \mathrm{~nm}$ in $\mathrm{MeCN}$ to $373 \mathrm{~nm}$ in $\mathrm{MeNO}_{2}$ including a $248 \mathrm{~nm}$ peak in $\mathrm{MeCOOH}^{2 b}$ When we measured the UV spectrum of TMSCl-AcONO ${ }_{2}$ mixture, we observed a weak absorption at $\lambda_{\max }$ of $458 \mathrm{~nm}$ and six strong peaks between 202 and $267 \mathrm{~nm}$ including two peaks at 246 and $252 \mathrm{~nm}$. One of the latter two absorptions can be assigned to $\mathrm{NO}_{2} \mathrm{Cl}$ in $\mathrm{MeCOOH}$ and the remaining five can arise from various chromophoric groups present in the mixture. We presume that the presence of $458 \mathrm{~nm}$ peak and 246 or $252 \mathrm{~nm}$ peak is a good indication for the formation of $\mathrm{NO}_{2} \mathrm{Cl}$ in the TMSCl-AcONO ${ }_{2}$ mixture. 


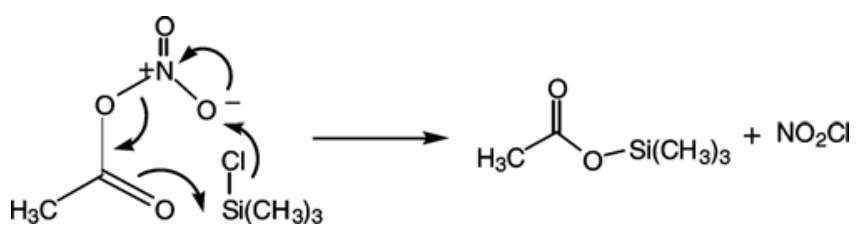

Scheme 2.

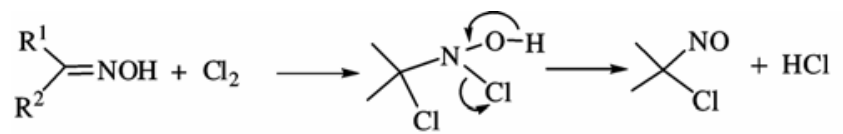<smiles>[R]C([R])=NON[N+](C)=O</smiles>
$\stackrel{\mathrm{R}^{2}}{\mathrm{R}}=\mathrm{NOH}+\mathrm{NO}_{2} \mathrm{Cl} \longrightarrow \mathrm{Cl}_{\mathrm{NO}_{2}}^{\mathrm{N}^{\mathrm{O}}-\mathrm{H}} \longrightarrow \chi_{\mathrm{Cl}}^{\mathrm{NO}}+\mathrm{HNO}_{2}$ $\underset{\mathrm{R}^{2}}{\mathrm{R}} \chi_{\mathrm{Cl}}^{\mathrm{NO}} \underset{\mathrm{N}_{2} \mathrm{O}_{4} \text { or } \mathrm{NOCl}}{\mathrm{NO}_{2} \mathrm{Cl} \text { or }} \underset{\mathrm{R}^{2}}{\mathrm{R}_{\mathrm{Cl}}^{1}} \chi_{\mathrm{NO}_{2}}^{\mathrm{NO}^{2}}$

Scheme 3.

It is interesting to note that $\mathrm{NO}_{2} \mathrm{Cl}$ is generated when TMSCl combines with $\mathrm{AcONO}_{2}$ but not with iso- $\mathrm{AmONO}_{2}$. We attribute this to the stronger nucleophilicity of the carbonyl oxygen of $\mathrm{AcONO}_{2}$, in initiating the attack on silicon as shown in scheme 2 , which is not possible by an alkyl nitrate.

The nitryl chloride may or may not react directly with the oximes. It is well known to undergo spontaneous decomposition to chlorine and nitric ox$\operatorname{ide}^{2 b, c}(7)$.

$$
2 \mathrm{NO}_{2} \mathrm{Cl} \rightarrow\left(2 \mathrm{Cl}^{\bullet} \rightarrow \mathrm{Cl}_{2}\right)+\left(2^{\circ} \mathrm{NO}_{2} \rightleftharpoons \mathrm{N}_{2} \mathrm{O}_{4}\right)
$$

The chlorine so formed would then react with oxime to produce gem-chloronitroso compounds ${ }^{32}$ (scheme 3 ), which are then oxidized by nitryl chloride or nitric oxide or even nitrosyl chloride which could form as shown in (8).

$$
2 \mathrm{NO}_{2} \mathrm{Cl}+\mathrm{H}_{2} \mathrm{O} \rightarrow \mathrm{Cl}_{2}+\mathrm{NOCl}+2 \mathrm{HNO}_{3}
$$

In separate experiments we found that treating gemchloronitroso compounds with TMSCl and $\mathrm{AcONO}_{2}$ converted them into gem-chloronitro compounds. This indicates that the chloronitroso compounds are initially formed, which are then oxidised in the second step (scheme 3).

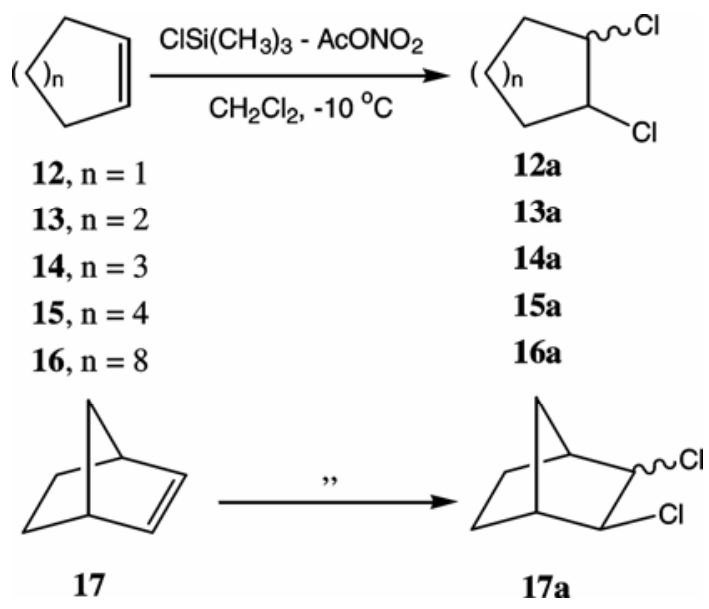

Scheme 4.

\subsection{Chlorination of olefins with TMSCl-AcONO mixture}

Since chlorine was suspected to be the main player in the conversion of oximes to gem-chloronitroso derivatives, we wanted to confirm its formation by trapping it through its addition to olefinic compounds. We treated six cycloalkenes 12-17 with chlorotrimethylsilane and acetyl nitrate. In each case we obtained the corresponding 1,2-dichlorocycloalkane as major product in good yield (scheme 4), accompanied by some minor products, which were not identified. The dichlorocycloalkanes were isolated in pure form by column chromatography and identified by their spectral characteristics (table 4) and comparing with authentic samples prepared by chlorination of the cycloalkenes with chlorine from an external source. We have not examined the stereochemistry of the dichloro compounds.

The formation of dichlorocycloalkanes $12 \mathbf{a}-\mathbf{1 7 a}$ from the cycloalkenes 12-17 on treating with $\mathrm{TMSCl}$ and $\mathrm{AcONO}_{2}$ is a clear indication that chlorine is formed, which then adds to the cycloalkenes.

Nitryl chloride is known to chlorinate olefins also by free radical mechanism. ${ }^{5 \mathrm{~d}, 33}$ However, in these cases the product is a mixture of several isomers, whereas in the present study we obtained essentially one isomer. Hence, we believe that here it is the addition of molecular chlorine by ionic mechanism.

\section{Acknowledgements}

A H A M thanks Indian Council for Cultural Relations (ICCR), New Delhi, for a fellowship under 
Cultural Exchange Programme. The work was partly supported by University Grants CommissionDepartmental Research Support (UGC-DRS) and University Grants Commission-Committee on Strengthening of Infrastructure for Science and Technology (UGC-COSIST) programmes, New Delhi. Some equipment used for the work is a donation to $\mathrm{G} \mathrm{N}$ by the Alexander von Humboldt Foundation, Germany.

\section{Supplementary information}

For supplementary information tables $\mathrm{S} 1$ and $\mathrm{S} 2$ see www.ias.ac.in/chemsci website.

\section{References}

1. (a) Mallya M N, Nagendrappa G, Prasad J S, Sridhar M A, Lokanath N K and Begum N S 2001 Tetrahedron Lett. 42 2565; (b) Mohammed A H A and Nagendrappa G 2003 Tetrahedron Lett. 44 2753; (c) Mallya M N and Nagendrappa G 2006 Arkivoc 14 155; (d) Vimala B C and Nagendrappa G 2009 J. Chem. Sci. 1211011

2. (a) Shechter H, Conrad F, Daulton A L and Kaplan R B 1952 J. Am. Chem. Soc. 74 3052; (b) Collis M J, Gintz F P, Goddard D R, Hebdon E A and Minkoff G J 1958 J. Chem. Soc. 438; (c) Eiserich J P, Cross C E, Jones A D, Halliwell B and van der Vliet A 1996 J. Biol. Chem. 27119199

3. (a) Schumacher H J and Sprenger G 1929 Z. Inorg. Chem. 182 139; (b) Johnston H S and Leighton Jr F 1953 J. Am. Chem. Soc. 753612

4. There is a large body of literature on this subject. Only a few references are given here. (a) Coffman $\mathrm{H}$ D, Roberts J M, Ravishankara A R, Williams E J, Lerner B M, Sommariva R, Bates T S, Coffmann D, Quinn P K, Dibb J E, Stark H, Burkholder J B, Talukdar R K, Meagher J, Fehsenfeld F C and Brown S S 2008 Nature Geoscience 1 324; (b) Kercher J P, Riedel T P and Thornton J A 2009 Atmos. Meas. Tech. 2, 193; (c) Roberts J M, Osthoff H D, Brown S S and Ravishankara A R 2008 Science 321 1059; (d) Karlsson R and Ljungström 1998 Atmos. Environ. 32 1711; (e) Behnke W, Scheer V and Zetzsch $1994 \mathrm{~J}$. Aerosol Sci. 25277

5. (a) Shvekhgeimer G A, Smirniyagin V A, Sadykov R A and Novikov S S 1968 Russ. Chem. Rev. 37 351; (b) Goddard D R 1958 J. Chem. Soc. 1955; (c) Steinkopf W and Kuhnel M 1942 Chem. Ber. 75 1323; (d) Martynov I V and Yurtanov A I 1989 Russ. Chem. Rev. 58 848; (e) Nonhebel D C and Walton J C 1974 Free radical chemistry; structure and mechanism (Cambridge University Press) pp 289; (f) Terada A and Hassner A 1967 Bull. Chem. Soc. Jpn. 40 1937; (g) Shin C, Yamaura M, Inui E, Ishida Y and Yoshimura J 1978 Bull. Chem. Soc. Jpn. 51 2618; (h) Shin
C-G, Yonezawa Y, Narukawa H, Nanjo K and Yoshimura 1972 J. Bull. Chem. Soc. Jpn. 45 3595; (i) Freeman J P and Emmons W D $1957 \mathrm{~J}$. Am. Chem. Soc. 79 1712; (j) Price C C and Sears C A 1953 J. Am. Chem. Soc. 75 3276; (k) Brand J C D and Stevens I D R 1958 J. Chem. Soc. 629

6. (a) Olah G A, Lin H C, Olah J A and Narang S C 1978 Proc. Natl. Acad. Sci. USA 75 1045; (b) Kuhn S $\mathrm{J}$ and Olah G A $1961 \mathrm{~J}$. Am. Chem. Soc. 83 4564; (c) Heal M R, Harrison M A J and Cape N J 2007 J. Atmos. Environ. 41 3515; (d) Harrison M A J, Barra S, Borghesi D, Vione D, Arsene C and Olariu R L 2005 Atmos. Environ. 39 231; (e) Kohnen S L, Mouithys-Mickalad A A, Deby-Dupont G P, Deby C M T, Hans P, Lamy M L and Noels A F 2003 Nitric Oxide 8170

7. Gintz F P, Goddard D R and Collis M J 1958 J. Chem. Soc. 445

8. Prostenik M V, Dumic M and Bosnjak N 1980 Monatsh. Chem. 111771

9. Borbulevych O Ya, Semenov A V, Vasin V A and Razin V V 2002 Acta Cryst. E58 0925

10. Dedon P C and Tannenbaum S R 2004 Arch. Biochem. Biophys. $\mathbf{4 2 3} 12$

11. Furnis B S, Hannaford A J, Smith P W G and Tatchell A R 2004 Vogel's textbook of practical organic chemistry (Singapore: Pearson Education) 5th edn, p. 1019

12. (a) Patil G S and Nagendrappa G 1999 J. Chem. Soc., Chem. Commun. 1079; (b) Bordwell F G and Garbisch Jr W $1960 \mathrm{~J}$. Am. Chem. Soc. 823588

13. Furnis B S, Hannaford A J, Smith P W G and Tatchell A R 2004 Vogel's textbook of practical organic chemistry (Singapore: Pearson Education) 5 th edn, p. 1259

14. Sakai I 1979 Bull. Chem. Soc. Jpn 523381

15. Hawthorne F M 1957 J. Am. Chem. Soc. 792515

16. Kretov A E 1961 Zhur. Obsh. Khim. 314043

17. Gupta A K, Acharya J, Pardasani D and Dubey D K 2007 Tetrahedron Lett. 48767

18. Kumar V and Kaushik M P 2005 Tetrahedron Lett. 468121

19. Slater C D and Harrison L W 1971 J. Org. Chem. 36 3561

20. Zaks A, Yabannavar A V, Dodds D R, Evans A C, Das P R and Malchow R 1996 J. Org. Chem. 618692

21. Walters T R, Zajac Jr W W and Woods J M 1991 J. Org. Chem. 56316

22. Kosinski M and Lodz III T N W 1964 Acta Chim. 993

23. Maffei S 1956 Ann. Chim. (Italy) 46604

24. Rheinboldt H and Dewald M 1927 Justus Liebigs Ann. Chem. $\mathbf{4 5 5} 300$

25. Boucenna M-C, Davidson J S, McKee A, Porte A L and Apperley D C $1995 \mathrm{~J}$. Chem. Soc. Perkin Trans. 271381

26. Mitchell S, Watson J S and Dunlop W 1950 J. Chem. Soc. 3440

27. Ohno M and Kawabe N 1966 Tetrahedron Lett. 33 3935

28. Curini M, Epifano F, Marcotullio M C, Rosati O and Rossi M 1999 Tetrahedron 556211 
29. (a) Boyer H J 1969 The chemistry of nitro and nitroso groups (eds) H Feuer and S Patai (New York: John Wiley) part 1; (b) Walters $\mathrm{T}$ R, Zajak W W and Woods J M 1991 J. Org. Chem. 56 316; (c) Terent'ev A O, Krylov I B, Ogibin Y N and Nikishin G I 2006 Synthesis 3819; (d) Corey E J and Estreicher H 1980 Tetrahedron Lett. 21 1117; (e) Ono N, Tamura R, Eto H, Hamamoto I and Nakatsuka T $1983 \mathrm{~J}$. Org. Chem. 48 3678; (f) Russell G A, Mudryk B, Ros F and Jawdosiuk M 1982 Tetrahedron 38 1059; (g) Fridman A L, Surkov V D and Novikov S S 1980 Russ. Chem. Rev. 491068

30. (a) Kyung J H and Clapp L B 1976 J. Org. Chem. 41 2024; (b) Kugelman M, Mallams A K and Vernay H F 1976 J. Chem. Soc. Perkin Trans. 11113

31. Mohammed A H A 2003 Ph D thesis, Bangalore University
32. (a) Kresze G, Mayer N M and Winkler J 1971 Liebigs Ann. Chem. 747 172; (b) Bosch T, Kresze G and Winkler J 1975 Liebigs Ann. Chem. 1009; (c) Tordeux M, Boumizane K and Wakselman C 1995 J. Fluorine Chem. 70 207; (d) Muller E, Fries D and Metzger H 1955 Chem. Ber. 88 1891; (e) Abele E and Lukevics E 2000 New J. Org. Synth. 32 235; (f) Kresze G, Ascher B, Braun H and Felber $\mathrm{H}$ 1987 Org. Prep. Proced. Int. 19 329; (g) Gowenlock B G and Richter-Addo G B 2004 Chem. Rev. 104 3315

33. (a) Brand J C D and Stevens I D R $1958 \mathrm{~J}$. Chem. Soc. 629; (b) Filimonov V D, Kulmanakova Yu Yu, Yasubov M S, Perederina I A, Chi K-W and Poleshchuk O Kh 2004 Russ. J. Org. Chem. 40917

34. Girija C R, Begum N S and Nagendrappa G 2004 Cryst. Eng. Comm. 6116 